\title{
Serosurvey of peste des petits ruminants virus in small ruminants from different agro-ecological zones of Nigeria
}

\begin{tabular}{|c|c|}
\hline Authors: & \\
\hline Timothy Y. Wo & $\mathrm{ma}^{1,2}$ \\
\hline Pius S. Ekong² & \\
\hline Dauda G. Bwa & \\
\hline John O. Ibu² & \\
\hline Louisa Ta'ama & \\
\hline Dyek Y. Dyek² & \\
\hline Ladi Saleh ${ }^{2}$ & \\
\hline David Shamak & \\
\hline Demo J.U. Kal & \\
\hline Dalan Bailey ${ }^{4}$ & \\
\hline Haruna M. Ka & $z^{2 e e m^{5}}$ \\
\hline Melvyn Quan & \\
\hline $\begin{array}{l}\text { Affiliations: } \\
{ }^{1} \text { Department }\end{array}$ & f Veterinary \\
\hline $\begin{array}{l}\text { Tropical Disea } \\
\text { of Pretoria, So }\end{array}$ & $\begin{array}{l}\text { ses, University } \\
\text { uth Africa }\end{array}$ \\
\hline $\begin{array}{l}{ }^{2} \text { Morbillivirus } \\
\text { Laboratory, } \mathrm{N} \\
\text { Veterinary Re } \\
\text { Nigeria }\end{array}$ & $\begin{array}{l}\text { Research } \\
\text { earch Institute, }\end{array}$ \\
\hline $\begin{array}{l}{ }^{3} \text { Animal Produ } \\
\text { Programme, A } \\
\text { Tafawa Balew } \\
\text { Nigeria }\end{array}$ & $\begin{array}{l}\text { ction } \\
\text { bubakar } \\
\text { University, }\end{array}$ \\
\hline $\begin{array}{l}{ }^{4} \text { School of Imr } \\
\text { Infection, Uni } \\
\text { Birmingham, }\end{array}$ & $\begin{array}{l}\text { nunity and } \\
\text { ersity of } \\
\text { Jnited Kingdom }\end{array}$ \\
\hline $\begin{array}{l}{ }^{5} \text { Department } \\
\text { Microbiology, } \\
\text { University Zar }\end{array}$ & $\begin{array}{l}\text { f Veterinary } \\
\text { Ahmadu Bello } \\
\text { a, Nigeria }\end{array}$ \\
\hline $\begin{array}{l}\text { Corresponder } \\
\text { email: } \\
\text { Timothy Wom } \\
\text { womaty@gm }\end{array}$ & $\begin{array}{l}\text { ce author and } \\
\text { il.com } \\
\text { ilcom }\end{array}$ \\
\hline $\begin{array}{l}\text { Dates: } \\
\text { Received: } 05 \\
\text { Accepted: } 14 \\
\text { Published: } 11\end{array}$ & $\begin{array}{l}\text { ug. } 2015 \\
\text { Mat. } 2015 \\
\text { Mar. } 2016\end{array}$ \\
\hline Read online: & \\
\hline 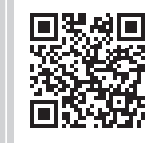 & $\begin{array}{l}\text { Scan this QR } \\
\text { code with your } \\
\text { smart phone or } \\
\text { mobile device } \\
\text { to read online. }\end{array}$ \\
\hline
\end{tabular}

Peste des petits ruminants, caused by the peste des petits ruminants virus (PPRV), is a highly contagious and economically important transboundary viral disease of domestic and wild small ruminants and a major hindrance to small-ruminant production in Nigeria. The seroprevalence and distribution of PPRV antibodies in small ruminants in rural households, farms, live animal markets and slaughter slabs across the six different agro-ecological zones of Nigeria were determined. A total of 4548 serum samples from 3489 goats and 1059 sheep were collected in 12 states. A PPRV competitive enzyme-linked immunosorbent assay was used to test the samples and the data analysed with $R$ statistical software version 3.0.1. The study animals included all ages and both sexes. The overall prevalence estimate of sera positive for PPRV antibodies was $23.16 \%$ ( $n=1018$ positive samples per 4548 total samples, $95 \%$ confidence interval: $21.79 \%-24.57 \%)$. There were significant differences in the seroprevalence between the states $(p=0.001)$. Taraba State had the highest seroprevalence of $29.51 \%$, whilst the lowest seroprevalence of $14.52 \%$ was observed in Cross River State. There were no significant differences in the PPRV seroprevalence between male and female animals $(p=0.571)$, age $(p=0.323)$ and between species $(p=0.639)$. These data indicate the current seroprevalence to PPRV in the small-ruminant population in Nigeria.

\section{Introduction}

Peste des petits ruminants (PPR) is a highly contagious and economically important transboundary viral disease of domestic and wild small ruminants (Balamurugan et al. 2010). Outbreaks of PPR occur regularly in small ruminants throughout Nigeria and are characterised by pyrexia, depression, anorexia, diarrhoea, respiratory distress, mucopurulent oculo-nasal discharge with matting of the eyelids, necrotic oral lesions that produce a foetid smell and sometimes abortion in pregnant animals. The disease is caused by the peste des petits ruminants virus (PPRV), which is classified in the genus Morbillivirus within the family Paramyxoviridae (King et al. 2012).

There are many documented reports of the endemic nature of PPRV in Nigeria (El-Yuguda et al. 2010; Emikpe \& Akpavie 2010; Ezeibe et al. 2008; Ibu et al. 2008; Isoun \& Mann 1972; Obi et al. 1983; Obidike et al. 2006; Odo 2003; Ogunsanmi et al. 2003; Okoli 2003; Shamaki 2002; Taylor \& Abegunde 1979; Ularamu et al. 2012). Outbreaks have continued to occur in the country during the last 40 years, despite the introduction of the tissue culture rinderpest vaccine against PPRV in the 1980s and the use of the homologous PPRV vaccine (Diallo 2003; Diallo et al. 1989) since 1998. The National Veterinary Research Institute Vom, Nigeria, produces a 50-dose PPRV vaccine vial using the Nigeria $75 / 1$ strain, with the recommendations that small ruminants must be vaccinated from 3 months of age and thereafter every 12 months.

Small ruminants play an important role in agricultural food production and in sustainable employment in Nigeria and the control and eradication of PPR is therefore a priority, in order to ease poverty and improve the health and husbandry of animals kept by resource-poor people in this developing country. This study was designed to determine the seroprevalence and distribution of PPRV antibodies in small ruminants in rural households, farms, live animal markets and slaughter slabs across different states in all the agro-ecological zones of Nigeria. This information will be helpful to develop a progressive control programme with the aim to eradicate PPR from Nigeria.

How to cite this article: Woma, T.Y., Ekong, P.S., Bwala, D.G., Ibu, J.O., Ta'ama, L., Dyek, D.Y. et al., 2016, 'Serosurvey of peste des petits ruminants virus in small ruminants from different agro-ecological zones of Nigeria', Onderstepoort Journal of Veterinary Research 83(1), Art. \#1035, 9 pages. http://dx.doi.org/10.4102/ojvr.v83i1.1035

Copyright: ( 2016. The Authors. Licensee: AOSIS. This work is licensed under the Creative Commons Attribution License. 


\section{Materials and methods}

\section{Study area}

Each agro-ecological zone consists of administrative structures called States, subdivided into local governments. Two states were selected at random from each agro-ecological zone: the north-eastern agro-ecological zone is montane savannah and samples were collected from Adamawa and Taraba States; the south-eastern agro-ecological zone is tropical rain forest and samples were collected from Anambra and Imo States; the south-southern agro-ecological zone is mangrove or swamp and samples were collected from Akwa Ibom and Cross River States; the north-central agro-ecological zone is Guinea or derived savannah and samples were collected from Kwara and Plateau States; the north-western agro-ecological zone is Sudan and Sahel savannah and samples were collected from Kano and Sokoto States; the south-western agro-ecological zone is tropical rain forest and samples were collected from Ogun and Ondo States (Iloeje 2001).

\section{Sample size and sample collection}

The OpenEpi v2 open-source calculator, SSPropor (Kevin, Andrew \& Minn 2009) was used to calculate the total number of samples to be collected per state using the equation:

Sample size $\begin{aligned}(n)= & \operatorname{DEFF} \times N p(1-p) /\left[d^{2} / Z_{1-\alpha / 2}^{2}\right. \\ & \times(N-1)+p(1-p)]\end{aligned}$

[Eqn 1]

where DEFF = design effect for cluster surveys, $N=$ population size, $p=$ hypothesised $\%$ frequency of outcome factor in a population and $d=$ confidence limits as $\pm \%$. The calculated sample size per state was 379 (Table 1).

The combined population of domestic small ruminants in Nigeria in 2007 was estimated at 90 million (FAOSTAT 2007).

Nigeria has a 36-state structure, and a figure of 2000000 small ruminants per state was estimated for sample size calculations (in effect an infinite population). A percentage frequency of outcome factor in the population was hypothesised to be $44 \% \pm 5 \%$ based on a study by Shamaki (2002). A confidence limit of $5 \%$ and design effect of one was used.

Multistage sampling was performed with four hierarchical stages. The first level of selection was the state. Two states were selected randomly from each agro-ecological zone of the country. Within each state, local governments, districts and villages were selected randomly. Within each selected village, animals were sampled from different homes, from the live animal market and from the slaughter slabs. These were selected purposely because of logistical constraints.

About $5 \mathrm{~mL}$ of blood was collected by venipuncture. Sera were separated within $24 \mathrm{~h}$ after centrifugation at a relative centrifugal force of 1000 for $10 \mathrm{~min}$. All samples were then stored at $-20{ }^{\circ} \mathrm{C}$ until used.

\section{Competitive enzyme-linked immunosorbent assay}

The commercially available competitive enzyme-linked immunosorbent assay (c-ELISA) kit (IDVET, France) for PPRV was used for this study. This diagnostic kit detects antibodies directed against the nucleoprotein of PPRV and was developed by a FAO reference laboratory (CIRAD-EMVT, Montpellier, France). The microplates were supplied in strips, already precoated with PPRV recombinant nucleoprotein. The kit contained anti-Nucleoprotein Horseradish peroxidase (NPHRP) concentrated conjugate $(10 \times)$, positive and negative controls, dilution buffers, wash concentrate $(20 \times)$, substrate solution and stop solution $\left(0.5 \mathrm{M} \mathrm{H}_{2} \mathrm{SO}_{4}\right)$. The test was performed according to the manufacturer's instructions (Libeau et al. 1995). The ELISA microplates were read with an immunoscan reader (Flow Laboratories, UK) with a filter of $450 \mathrm{~nm}$. The optical density (OD) was recorded and the test was validated when the mean value of the negative control

TABLE 1: Apparent and true prevalence of peste des petits ruminants virus antibodies in small ruminants in Nigeria, 2010-2013.

\begin{tabular}{|c|c|c|c|c|c|c|c|}
\hline Category & Region & Number of samples analysed & Number positive & Apparent prevalence $(\%)$ & TP $(\%)$ & $X^{2}$ & $p$ \\
\hline \multirow[t]{12}{*}{ State } & Adamawa & 379 & 76 & 20.05 & 20.52 & 30.9 & 0.001 \\
\hline & Taraba & 379 & 106 & 27.97 & 29.51 & - & - \\
\hline & Anambra & 379 & 74 & 19.53 & 19.92 & - & - \\
\hline & Imo & 379 & 102 & 26.91 & 28.31 & - & - \\
\hline & Akwalbom & 379 & 94 & 24.80 & 25.91 & - & - \\
\hline & Cross River & 379 & 56 & 14.76 & 14.52 & - & - \\
\hline & Plateau & 379 & 79 & 20.84 & 21.41 & - & - \\
\hline & Kwara & 379 & 101 & 26.65 & 28.01 & - & - \\
\hline & Kano & 379 & 108 & 28.49 & 30.11 & - & - \\
\hline & Sokoto & 379 & 84 & 22.16 & 22.91 & - & - \\
\hline & Ogun & 379 & 67 & 17.68 & 17.82 & - & - \\
\hline & Ondo & 379 & 71 & 18.73 & 19.02 & - & - \\
\hline \multirow[t]{2}{*}{ Sex } & Male animals & 1925 & 421 & 21.87 & 22.58 & 0.321 & 0.571 \\
\hline & Female animals & 2623 & 597 & 22.76 & 23.59 & - & - \\
\hline \multirow[t]{2}{*}{ Species } & Sheep & 1059 & 244 & 23.04 & 23.91 & 0.220 & 0.639 \\
\hline & Goat & 3489 & 774 & 22.18 & 22.93 & - & - \\
\hline \multirow[t]{2}{*}{ Age } & Adult & 3040 & 664 & 21.38 & 22.55 & 0.977 & 0.323 \\
\hline & Young & 1508 & 354 & 23.48 & 24.41 & - & - \\
\hline Total & & 4548 & 1018 & 22.38 & 23.16 & - & - \\
\hline
\end{tabular}


OD (ODNC) was greater than 0.7 and the mean value of the positive control OD was less than 0.3 of the ODNC.

The OD values were converted to competition percentage $(\mathrm{CP})$ using the following formula: $\mathrm{CP}=\mathrm{OD}$ sample/ODNC $\times$ 100. The samples with $\mathrm{CP} \leq 35 \%$ (cut-off) were considered positive for PPRV infection.

\section{Statistical analysis}

The overall and group apparent prevalence (total positive/ total sample analysed) and the exact binomial 95\% confidence intervals (CI) were computed. Pearson's chi-squared test was used to determine if there were significant differences in the number of positive and negative test results within each variable. A $p<0.05$ was considered significant for all tests. The true prevalence (TP) together with 95\% CI for all categories was calculated using the Rogan-Gladen adjusted estimator of 'true' prevalence (Rogan \& Gladen 1978). TP was calculated using the following equation:

$\mathrm{TP}=(\mathrm{AP}+\mathrm{Sp}-1) /(\mathrm{Se}+\mathrm{Sp}-1)$

[Eqn 2]

where $\mathrm{AP}=$ apparent prevalence, $\mathrm{Sp}=$ specificity and $\mathrm{Se}=$ sensitivity. The sensitivity of the c-ELISA test has been reported to be $90 \%$ and specificity $98 \%$ (Saliki et al. 1993). All analyses were performed in $\mathrm{R}$ statistical software version 3.0.1 (R 2015).

\section{Results}

At a 95\% confidence level, a sample size of 379 animals per state was calculated. A total of 4548 field serum samples were collected from 12 states across the agro-ecological zones of the country. No animal was known to have been vaccinated against PPRV before or at the time of sampling. Some animals appeared to have clinical signs compatible with PPR during sampling (Figure 1a-e). Small ruminants were transported in vehicles that were often overcrowded, over long distances from the north of the country to the live animal markets in the south (Figure 2a). On arrival at the markets, the animals were tied together as they awaited buyers (Figure 2b).

The overall apparent prevalence estimate of sera positive for PPRV antibodies was 22.38\% $(n=1018 / 4548,95 \%$ CI: $21.79-24.57)$, with a range of $14.5 \%-30.1 \%$. The overall TP estimate was $23.16 \%$ (Table 1 ).

There were significant differences in the distribution of PPRV antibodies in small ruminants between states ( $p=$ 0.001 ) (Table 1, Figure 3). The highest seroprevalence was in Taraba State $(29.51 \%)$, whilst the lowest seroprevalence was observed in Cross River State (14.52\%). The highest seroprevalence of PPRV in sheep where $n>6$ was in Kano State $(33.12 \%, n=157)$ and in goats it was in Taraba State
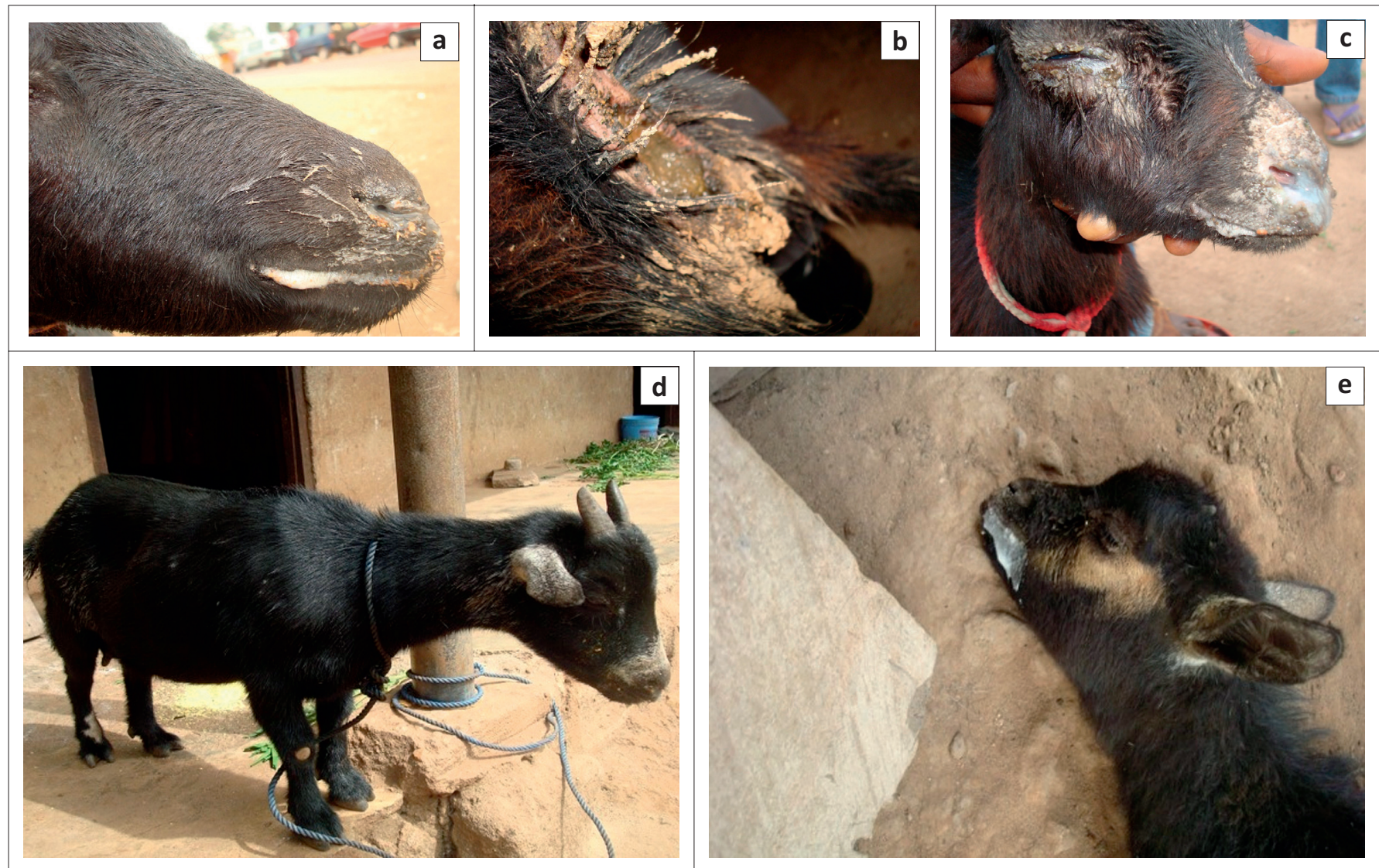

Source: Photos taken by Dr Timothy Yusufu Woma

FIGURE 1: Clinical signs (compatible with Peste des petits ruminants) observed during sampling (2010-2013) in various locations in Nigeria: (a) frothy salivation and muco-purulent nasal discharge; (b) soiled anal region because of profuse diarrhoea; (c) matted eyelids, salivation and nasal discharges; (d) raised hair coat, depression and increased rectal temperature and (e) frothy salivation and death. 

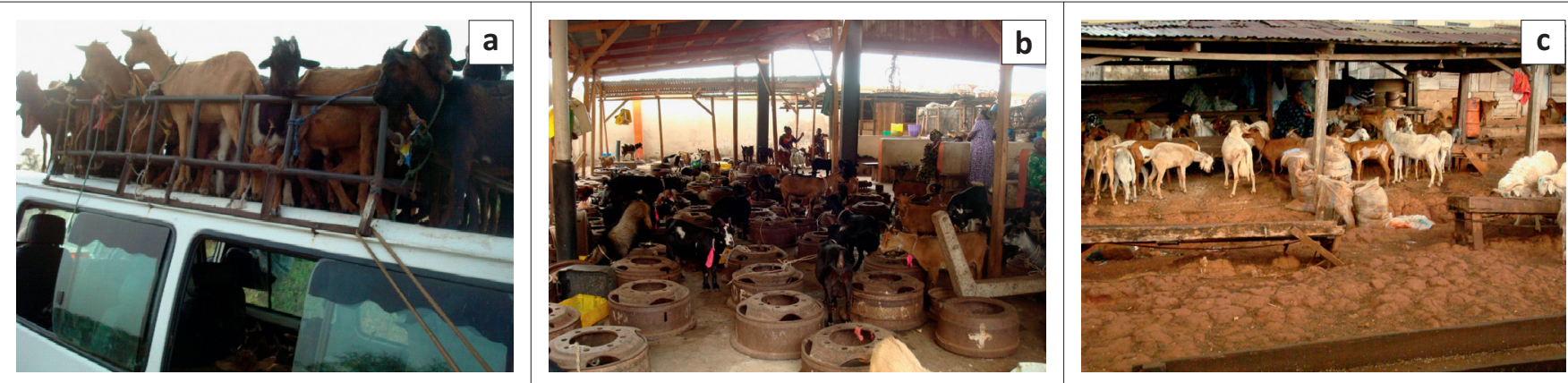

Source: Photos taken by Dr Timothy Yusufu Woma

Note: The animals were tied together as they awaited buyers. At the end of the day, the animals not sold were returned to the flock until the next market day.

FIGURE 2: (a) Small ruminants were transported in an overcrowded vehicle from the north-eastern part of the country to the south. Note the exposure to weather elements (sun, rain) in addition to the stress of transportation over long distances without feed or water. (b and c) Live animal market in a south-western Nigerian city.

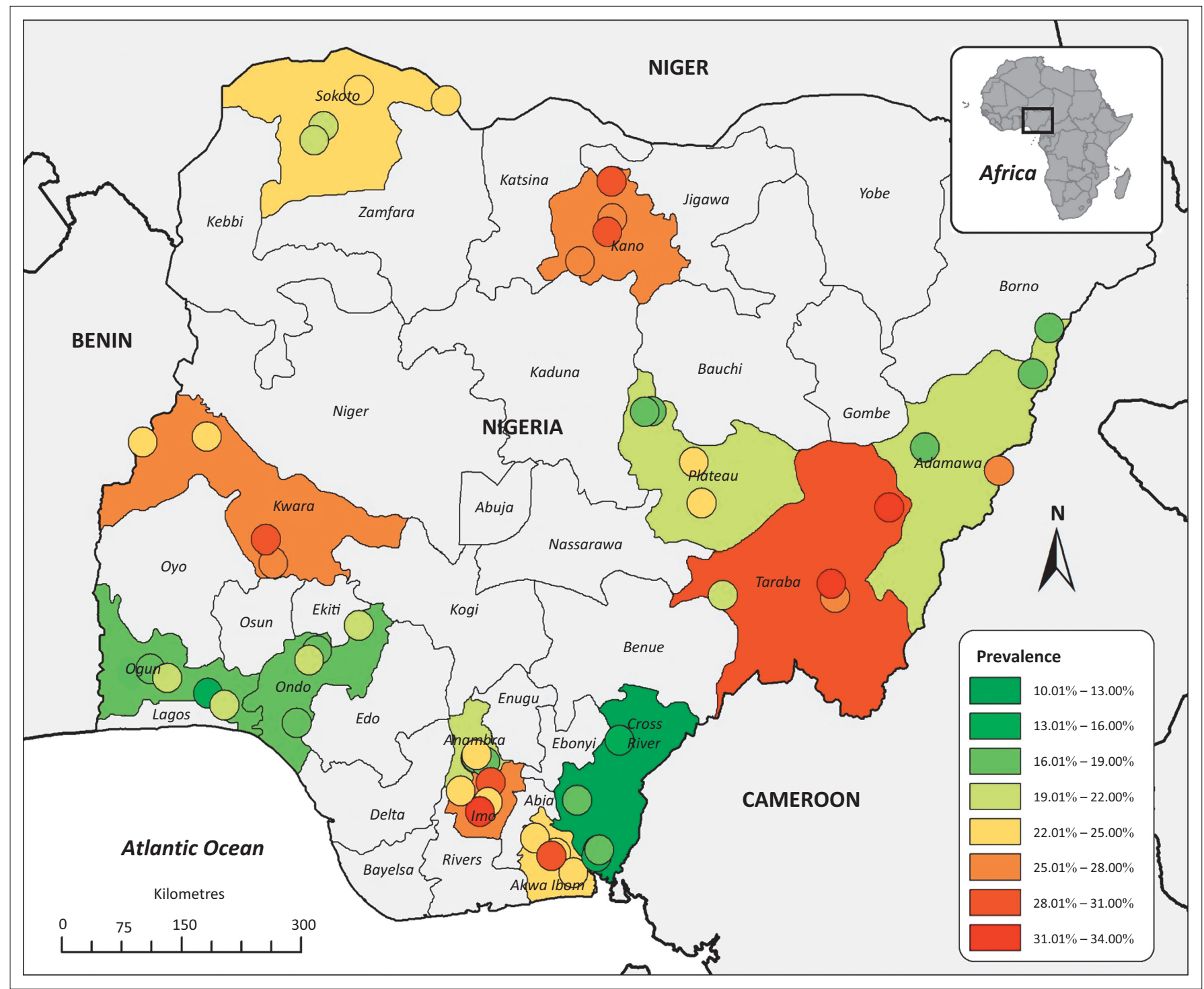

Source: Map was produced in ArcGIS version 10.2

FIGURE 3: Prevalence of peste des petits ruminants virus antibodies in each locality indicated by coloured circles. The colour of each state indicates the overall prevalence in that state.

$(27.97 \%, n=236)$ (Figure 4). The seroprevalence varied between localities, with a range of $12.64 \%$ (Ikot-Omin, Cross River State) to $33.33 \%$ (Kassa, Taraba State) (Figure 4). No spatial pattern was evident in the distribution of PPRV antibodies in small ruminants - the seroprevalence did not appear to be higher in states neighbouring other countries, nor higher in one region of the country.

From the 4548 small ruminants that were sampled, $42.3 \%$ were male animals and $57.7 \%$ were female animals (Table 1 ). 


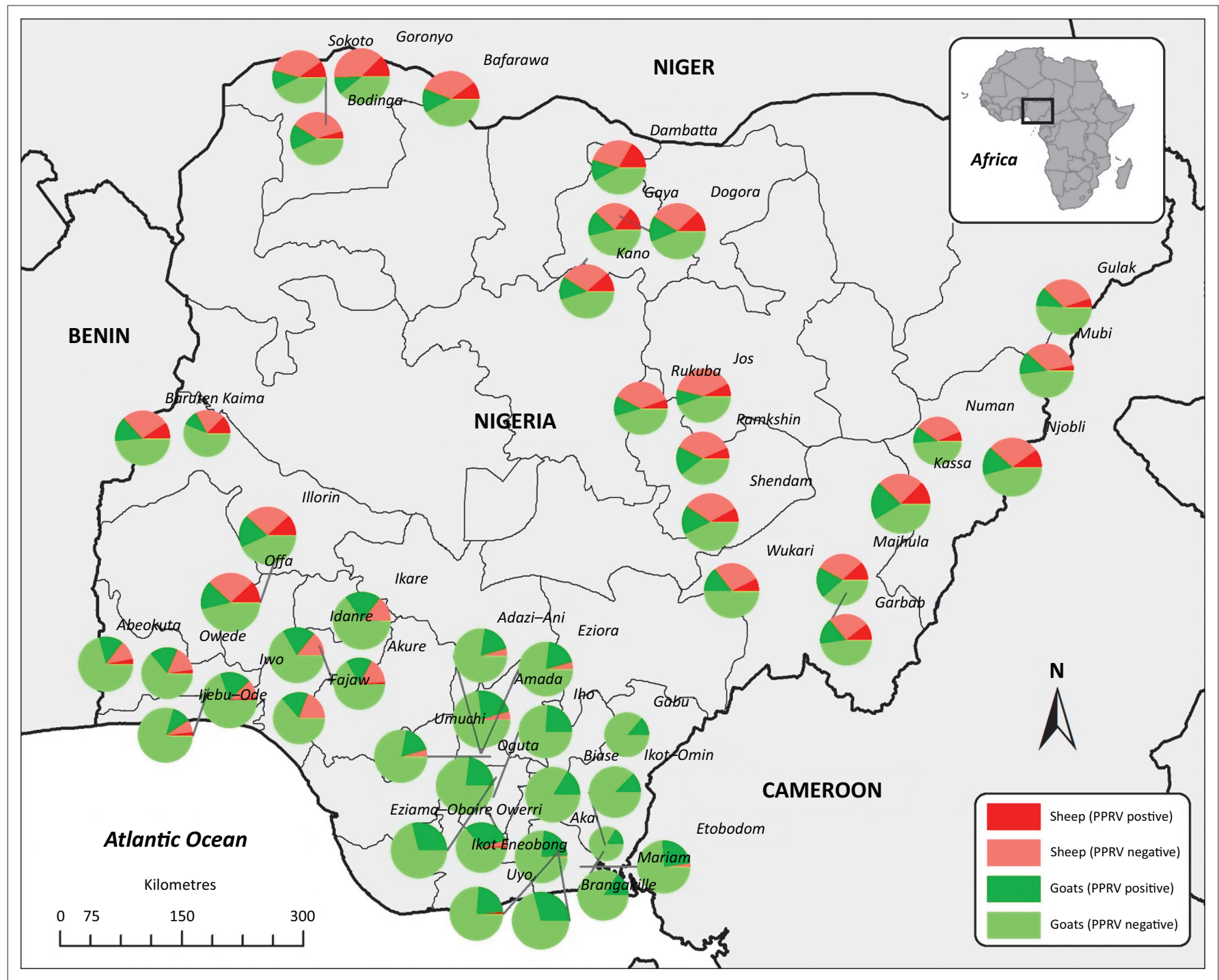

Source: Map was produced in ArcGIS version 10.2

FIGURE 4: The proportion of sheep and goats seropositive to peste des petits ruminants virus in Nigeria. The size of the pie symbol is relative to the number of samples collected.

True prevalence was $22.58 \%$ for male animals and $23.59 \%$ for female animals. There was no significant difference in the PPRV seroprevalence between male and female small ruminants $(p=0.571)$.

The animals that were sampled ranged in age from 3 months to 3 years. The TP of PPRV in animals above 1 year of age was $22.55 \%$ and $24.40 \%$ in animals between 3 and 12 months of age. There was no significant difference between the seroprevalence of PPRV in small ruminants over 1 year of age and those between 3 and 12 months of age $(p=0.323)$ (Table 1$)$.

A total of 3489 serum samples were collected form goats and 1059 serum samples from sheep. The TP in goats was $22.93 \%$ and it was $23.91 \%$ in sheep. There was no significant difference between the seroprevalence of PPRV in sheep and goats $(p=0.639)$ (Table 1$)$.

The sample size in each locality varied from 43 (Ikot Eneobong, Cross River State) to 111 (Kassa, Taraba State) with a median of 95 (Figure 4). In most localities in the south of Nigeria, sheep were seronegative for PPRV. In this region, the sample sizes in sheep were either small (Akwa Ibom, Anambra and Imo States) or no sheep were available for sampling (Cross River State), as most farmers breed goats and sheep are scarce. However, in Idanre and Fajaw, both in Ondo State, all 14 and 17 sheep, respectively, were seronegative for PPRV. The highest seroprevalence of PPRV in sheep in a locality where the sample size was greater than two was in Gaya, Kano State $(38.24 \%, n=34)$. The largest number of sheep sampled in a locality $(n=44)$ was in Bafarawa (Sokoto State), where the seroprevalence of antibodies to PPRV in sheep was $22.73 \%$.

Goats were present in all localities sampled, with a range of 43 (Ikot Eneobong, Cross River State) to 104 (Brangaville, Akwa Ibom State). The prevalence in goats ranged from $12.36 \%$ (Ijebu-Ode, Ogun State) to 34.00\% (Maihula, Taraba State) (Figure 4).

The seroprevalence of PPRV antibodies in each animal category was very similar $(20.44 \%$ in male adult sheep, 
$22.29 \%$ in female adult sheep, $21.64 \%$ in young male sheep, $23.78 \%$ in young female sheep, $23.89 \%$ in adult male goats, $22.09 \%$ in adult female goats, $26.21 \%$ in young male goats and $24.02 \%$ in young female goats). The highest seroprevalence was $66.67 \%$ in young female sheep from Kwara State $(n=18)$.

\section{Discussion}

Analysis of 4548 samples from sheep and goats confirmed the endemic nature and wide distribution of PPRV throughout Nigeria. This study found an overall current seroprevalence of PPRV antibodies in small ruminants in Nigeria to be $23.16 \%$. Taylor and Abegunde (1979) in the 1970s reported a seroprevalence of $57 \%$ and $44 \%$ in sheep and goats respectively. Obi et al. (1983) reported 52.2\% and $53.7 \%$ in sheep and goats in the 1980s, whilst Shamaki (2002) reported a seroprevalence of $44 \%$ from samples analysed between 1995 and 1999. These differences may be because of the sampling locations, sample frames, seasons of the year, different sampling techniques and laboratory tests used. It is also possible that the higher seroprevalence obtained previously was because of sampling during outbreaks. The worldwide eradication of rinderpest virus, which cross-reacts with PPRV in serological tests, may also have been responsible for the lower seroprevalence we found in this study.

These results are similar to a study in Ethiopia, which reported a seroprevalence of $33 \%$ in sheep and $67 \%$ in goats in the 1990s, but another study a decade later found the seroprevalence to be $9 \%$ in goats and $13 \%$ in sheep (Abraham et al. 2005; Roeder et al. 1994). The difference was less in Sudan (51.9\% compared to $67.2 \%$ ) in studies conducted 10 years apart (Haroun et al. 2002; Saeed et al. 2010).

Taraba State in the north-east agro-ecological zone had the highest seroprevalence rate of $29.51 \%$, whilst Cross River State in the south-southern agro-ecological zone had the lowest seroprevalence rate of $14.52 \%$. This observation may be because of the prevailing management practices in the various states and rainfall, which affects the growth of grasses. Most of the small ruminants in Taraba State are on a free range (agro-pastoralism) system because the farmlands for crops are at a distance from most villages and the zone is a savannah with a longer dry season period. Most animals in Cross River State are tied at home and grass is provided because crops are planted in the backyard. Cross River State is a rain forest zone with abundant rain that enables grass to grow almost all the year round. The sheep breeds observed in Taraba State were of the Uda, Balami and Yankassa breeds, whilst those seen in Cross River State were predominantly of the West African dwarf (WAD) stock. The WAD breeds of goats were also seen in Cross River State, while those in TarabaState were a mix of both the WAD and the Sokoto Red. It is not clear whether these breed differences in small ruminants had any effect on the difference in seroprevalence rates observed in the two states.

Transportation, management practices and marketing play major roles in the epidemiology of PPRV. We observed that animals from different households and localities are usually transported together in close proximity (Figure 2a) to the market. At the market, the animals are tied together (Figure 2b) in stalls as they await buyers. Any animal not sold is returned to the flock and new animals bought also end up in new flocks. These practices are conducive to outbreaks of diseases. New infections leading to outbreaks normally occur when animals are transported together or when they are tied together (transportation stress, overcrowding and malnutrition) in the live animal markets or kept for safety reasons with a relative from another locality.

In this study, there was an over-representation of female animals (2623 female animals and 1925 male animals). This may be because of the practice of sacrificing male animals when the need to sell or slaughter animals arises.

The c-ELISA is an ideal test to carry out a serological survey of PPRV antibodies in small ruminants. The c-ELISA was used in this study because of the merits it has over other serological techniques, which are more laborious and time consuming.

The results of this study may have been biased by the sampling technique employed. Because of the logistical constraints and the complexity of the pastoral husbandry practices, it was not possible to systematically select the different villages, farms, households and the animals to include in this study. Live sheep and goat markets and slaughter slabs were also sampled randomly in each locality visited. A more accurate seroprevalence may emerge if randomised sampling is carried out where the actual small-ruminant population in each state (data such as these are currently not available in Nigeria) is taken into account.

An important observation during the course of sampling is the apparent lack of awareness amongst the small-ruminant owners of the vaccination status of their flocks. The control and eradication of PPR is a priority in order to ease poverty and improve the health and husbandry of animals kept by people in developing countries. It is encouraging to note that between 18 and 23 November 2013, heads of veterinary laboratories and directors of veterinary services from the ECOWAS subregion gathered in Lagos to develop a framework for the progressive control of PPR in the region. This type of subregional approach also took place in southern Africa and a PanAfrican strategy for the progressive control of PPRV has also been developed (Elsawalhy et al. 2010).

This study provides an overview of the current antibody seroprevalence to PPRV in the small-ruminant population in Nigeria and also confirms a low level of awareness about vaccination amongst small-holder farmers in rural settings.

\section{Acknowledgements}

This work was supported by a grant (RFA 2 No.48) from the Agricultural Research Council of Nigeria through the 
Competitive Agricultural Research Grant Scheme. We sincerely thank all the field staff who helped during sample collection and other logistics. D. Shamaki is a recipient of an IAEA project on PPR (CRP D32026). T.Y. Woma is a recipient of an IAEA intern fellowship.

\section{Competing interests}

The authors declare that they have no financial or personal relationships which may have inappropriately influenced them in writing this article.

\section{Authors' contributions}

T.Y.W. was responsible for experimental and project design and wrote the draft manuscript. P.S.E. performed the statistical analysis D.G.B., J.O.I., L.T., D.Y.D. and L.S. performed most of the experiments. H.M.K., D.J.U.K., D.B. and D.S. made conceptual contributions. M.Q. was the project leader and contributed in writing the manuscript.

\section{References}

Abraham, G., Sintayehu, A., Libeau, G., Albina, E., Roger, F., Laekemariam, Y. et al., 2005, 'Antibody seroprevalences against peste des petits ruminants (PPR) virus in camels, cattle, goats and sheep in Ethiopia', Preventive Veterinary Medicine 70 camels,

Balamurugan, V., Sen, A., Venkatesan, G., Yadav, V., Bhanot, V., Riyesh, T. et al., 2010, 'Sequence and phylogenetic analysis of the structural genes of virulent isolates and vaccine strains of peste des petits ruminants virus from India', Transboundary and Emerging Diseases 57, 352-364.

Diallo, A., 2003, 'Control of PPR: Classical and new generation of vaccines', DevBiol (Basel Karger) 114, 85-91.

Diallo, A., Taylor, W.P., Lefevre, P.C. \& Provost, A., 1989, 'Atténuationd'unesouche de virus de la peste des petits ruminants: Candidat pour un vaccine homologue vivant', Revue d'élevage et de médecine vétérinaire des pays tropicaux 42, 311-319.

Elsawalhy, A., Mariner, J.C., Chibeu, D., Wamwayi, H., Wakhusama, S., Olaho-Mukani, W. et al., 2010, 'PanAfrican strategy for the progressive control of peste des petits ruminants (panAfrican PPR strategy)', Bulletin of Animal Health and Production in Africa 58, 185-193.

El-Yuguda, A., Chabiri, L., Adamu, F. \& Baba, S.S., 2010, 'Peste des petits ruminants virus (PPRV) infection among small ruminants slaughtered at the central abattoir, Maiduguri, Nigeria', Sahel Journal of Veterinary Science 8, 51-62.

Emikpe, B.O. \& Akpavie, S.O., 2010, 'The prevalence of peste des petits ruminants virus antibodies in goats from selected rural and urban communities in Ibadan, Nigeria', Bulletin of Animal Health and Production in Africa 58, 147-153.

Ezeibe, M.C.O., Okoroafor, O.N., Ngene, A.A., Eze, J.I., Eze, I.C. \& Ugonabo, J.A.C. 2008, 'Persistent detection of peste des petits ruminants antigen in the faeces of recovered goats', Tropical Animal Health and Production 40, 517-519.
FAO Statistics, 2007, viewed 21 May 2009, from http://faostat.fao.org/default.aspx

Haroun, M., Hajer, I., Mukhtar, M. \& Ali, B.E., 2002, 'Detection of antibodies against Peste des Petits Ruminants virus in sera of cattle, camels, sheep and goats in Sudan', Veterinary Research Communications 26, 537-541.

Ibu, O., Salihu, S., Luther, J., Suraj, K., Ceaser, A., Abechi, A. et al., 2008, 'Evaluation of peste des petits ruminants and rinderpest virus infection of camels in Borno and Kano states of Nigeria', Nigerian Veterinary Journal 29, 76-77.

Iloeje, N.P., 2001, A new geography of Nigeria, New rev. edn., Longman Nigeria PLC, Ikeja, Lagos, p. 200.

Isoun, T.T. \& Mann, E.D., 1972, 'A stomatitis and pneumoenteritis of sheep in Nigeria', Bullentin of Epizootic Diseases in Africa 20, 167-174.

Kevin, M.S., Andrew, D. \& Minn, S., 2009, 'OpenEpi: A web-based epidemiologic and statistical calculator for public health', Public Health Report 124(3), and 474 .

King, A.M.Q., Adams, M.J., Carstens, E.B. \& Lefkowitz, E.J. (eds.), 2012, Virus taxonomy: Classification and nomenclature of viruses: Ninth report of the International Committee on Taxonomy of Viruses (ICTV), Elsevier Academic Press, San Diego, CA.

Libeau, G., Préhaud, C., Lancelot, R., Colas, F., Guerre, L., Bishop, D.H. et al., 1995, 'Development of a competitive ELISA for detecting antibodies to the peste des petits ruminants virus using a recombinant nucleoprotein', Research in Veterinary Science 58(1), 50-55.

Obi, T.U., Ojo, M.O., Durojaiye, O.A., Kasali, O.B., Akpavie, S.O. \& Opasina, B.A. 1983 'PPR in goats in Nigeria: Clinical, microbiological and pathological features', Zentralb/ Veterinarmed B. 30, 751-761.

Obidike, R., Ezeibe, M., Omeje, J. \& Ugwuomarima, K., 2006, 'Incidence of peste des petits ruminants haemagglutinins in farm and market goats in Nsukka, Enugu state, Nigeria', Bulletin of Animal Health and Production in Africa 54 $148-150$.

Odo, B.I. 2003, 'Comparative study of some prevalent diseases of ecotype goats reared in south-eastern Nigeria', Small Ruminant Research 50, 203-207.

Ogunsanmi, A., Awe, E., Obi, T. \& Taiwo, V., 2003, 'Peste des petits ruminants virus (PPR) antibodies in African Gray Duiker (Sylvicapragrimmia)', African Journal of Biomedical Research 6, 59-61.

Okoli, I.C., 2003, 'Incidence and modulating effects of environmental factors on trpanosomosis, peste des petits ruminants (PPR) and bronchopneumonia of West African dwarf goats in Imo state, Nigeria', LivestockResearch for Rural Development 15, 9-11.

Roeder, P.L., Abraham, G., Kenfe, G. \& Barrett, T., 1994, 'PPR in Ethiopian goats', Tropical Animal Health and Production 26(2), 69-70.

Rogan, W.J. \& Gladen, B., 1978, 'Estimating prevalence from the results of a screening test', American Journal of Epidemiology 107, 71-76.

Saeed, I.K., Ali, Y.H., Khalafalla, A.I. \& Rahman-Mahasin, E.A., 2010, 'Current situation of Peste des Petits Ruminants (PPR) in the Sudan', Tropical Animal Health and Production 42, 89-93.

Saliki, J., Libeau, G., House, J.A., Mebus, A. \& Dubov, E.J., 1993, 'Monoclonal antibody based blocking ELISA for specific detection and titration of PPR virus antibody in caprine and ovine sera', Journal of Clinical Microbiology 31, 1075-1082.

Shamaki, D., 2002, 'Some aspects of serological and molecular epidemiology of Peste des Petits Ruminants (PPR) in Nigeria', PhD thesis, University of Ibadan, Nigeria.

Taylor, W.P. \& Abegunde, A., 1979, 'The isolation of peste des petits ruminants virus from Nigerian sheep and goats', Research in Veterinary Science 26, 94-96.

Ularamu, H.G., Owolodun, O.A., Woma, T.Y., Audu, B.J., Aaron, G.B., Chollom, S.C. et al., 2012, 'Molecular diagnosis of recent suspected outbreaks of peste des petits ruminants (PPR) in Yola, Adamawa State, Nigeria', African Journal of Biotechnology 11, 1158-1162. 


\section{Appendix 1}

TABLE 1-A1: Small-ruminant peste des petits ruminants virus seroprevalence survey from different localities in Nigeria, $2010-2013$.

\begin{tabular}{|c|c|c|c|c|c|c|c|c|c|c|c|c|c|c|}
\hline Province & Town & Latitude & Longitude & $\begin{array}{c}\text { Sheep } \\
\text { positive }\end{array}$ & $\begin{array}{c}\text { Sheep } \\
\text { negative }\end{array}$ & $\begin{array}{l}\text { Sheep } \\
\text { collected }\end{array}$ & $\begin{array}{c}\text { Goat } \\
\text { positive }\end{array}$ & $\begin{array}{c}\text { Goat } \\
\text { negative }\end{array}$ & $\begin{array}{c}\text { Goat } \\
\text { collected }\end{array}$ & $\begin{array}{c}\text { Total } \\
\text { positive }\end{array}$ & $\begin{array}{c}\text { Total } \\
\text { Collected }\end{array}$ & $\begin{array}{l}\text { Prev_ } \\
\text { sheep }\end{array}$ & $\begin{array}{l}\text { Prev_ } \\
\text { goats }\end{array}$ & $\begin{array}{l}\text { Prev } \\
\text { Total }\end{array}$ \\
\hline Adamawa State & Gulak & 10.806 & 13.456 & 5 & 32 & 37 & 11 & 50 & 61 & 16 & 98 & 13.51 & 18.03 & 16.33 \\
\hline Adamawa State & Mubi & 10.300 & 13.267 & 3 & 33 & 36 & 13 & 45 & 58 & 16 & 94 & 8.33 & 22.41 & 17.02 \\
\hline Adamawa State & Njobli & 9.227 & 12.883 & 11 & 31 & 42 & 17 & 50 & 67 & 28 & 109 & 26.19 & 25.37 & 25.69 \\
\hline Adamawa State & Numan & 9.483 & 12.050 & 5 & 26 & 31 & 9 & 38 & 47 & 14 & 78 & 16.13 & 19.15 & 17.95 \\
\hline Akwa Ibom State & Aka & 5.183 & 7.650 & 0 & 1 & 1 & 20 & 68 & 88 & 20 & 89 & 0.00 & 22.73 & 22.47 \\
\hline Akwa Ibom State & Brangaville & 4.983 & 7.833 & 0 & 1 & 1 & 30 & 74 & 104 & 30 & 105 & 0.00 & 28.85 & 28.57 \\
\hline Akwa Ibom State & Etobodom & 4.800 & 8.083 & 0 & 2 & 2 & 22 & 68 & 90 & 22 & 92 & 0.00 & 24.44 & 23.91 \\
\hline Akwa Ibom State & Uyo & 5.017 & 7.883 & 1 & 0 & 1 & 21 & 71 & 92 & 22 & 93 & 100.00 & 22.83 & 23.66 \\
\hline Anambra State & Adazi-Ani & 6.064 & 6.973 & 0 & 4 & 4 & 17 & 72 & 89 & 17 & 93 & 0.00 & 19.10 & 18.28 \\
\hline Anambra State & Amada & 6.102 & 6.987 & 0 & 5 & 5 & 23 & 76 & 99 & 23 & 104 & 0.00 & 23.23 & 22.12 \\
\hline Anambra State & Eziora & 6.070 & 6.986 & 0 & 4 & 4 & 18 & 73 & 91 & 18 & 95 & 0.00 & 19.78 & 18.95 \\
\hline Anambra State & Umuchi & 6.025 & 7.084 & 0 & 4 & 4 & 16 & 71 & 87 & 16 & 91 & 0.00 & 18.39 & 17.58 \\
\hline Cross Rivers State & Biase & 5.602 & 8.121 & 0 & 0 & 0 & 16 & 82 & 98 & 16 & 98 & - & 16.33 & 16.33 \\
\hline Cross Rivers State & Gabu & 6.267 & 8.600 & 0 & 0 & 0 & 9 & 58 & 67 & 9 & 67 & - & 13.43 & 13.43 \\
\hline Cross Rivers State & Ikot Eneobong & 5.056 & 8.372 & 0 & 0 & 0 & 7 & 36 & 43 & 7 & 43 & - & 16.28 & 16.28 \\
\hline Cross Rivers State & Ikot-Omin & 5.050 & 8.357 & 0 & 0 & 0 & 11 & 76 & 87 & 11 & 87 & - & 12.64 & 12.64 \\
\hline Cross Rivers State & Mariam & 4.975 & 8.337 & 0 & 0 & 0 & 13 & 71 & 84 & 13 & 84 & - & 15.48 & 15.48 \\
\hline Imo State & Eziama-Obaire & 5.797 & 7.144 & 0 & 0 & 0 & 29 & 71 & 100 & 29 & 100 & - & 29.00 & 29.00 \\
\hline Imo State & Iho & 5.577 & 7.115 & 0 & 0 & 0 & 22 & 70 & 92 & 22 & 92 & - & 23.91 & 23.91 \\
\hline Imo State & Oguta & 5.705 & 6.806 & 1 & 1 & 2 & 23 & 78 & 101 & 24 & 103 & 50.00 & 22.77 & 23.30 \\
\hline Imo State & Owerri & 5.477 & 7.025 & 1 & 3 & 4 & 26 & 54 & 80 & 27 & 84 & 25.00 & 32.50 & 32.14 \\
\hline Kano State & Dambatta & 12.426 & 8.509 & 16 & 27 & 43 & 12 & 40 & 52 & 28 & 95 & 37.21 & 23.08 & 29.47 \\
\hline Kano State & Dogora & 12.013 & 8.521 & 12 & 29 & 41 & 15 & 44 & 59 & 27 & 100 & 29.27 & 25.42 & 27.00 \\
\hline Kano State & Gaya & 11.867 & 8.467 & 13 & 21 & 34 & 14 & 41 & 55 & 27 & 89 & 38.24 & 25.45 & 30.34 \\
\hline Kano State & Kano & 11.539 & 8.158 & 11 & 28 & 39 & 13 & 43 & 56 & 24 & 95 & 28.21 & 23.21 & 25.26 \\
\hline Kwara State & Baruten & 9.550 & 3.231 & 9 & 27 & 36 & 14 & 47 & 61 & 23 & 97 & 25.00 & 22.95 & 23.71 \\
\hline Kwara State & Illorin & 8.474 & 4.619 & 12 & 27 & 39 & 19 & 44 & 63 & 31 & 102 & 30.77 & 30.16 & 30.39 \\
\hline Kwara State & Kaima & 9.604 & 3.947 & 9 & 15 & 24 & 8 & 41 & 49 & 17 & 73 & 37.50 & 16.33 & 23.29 \\
\hline Kwara State & Offa & 8.217 & 4.700 & 13 & 29 & 42 & 17 & 51 & 68 & 30 & 110 & 30.95 & 25.00 & 27.27 \\
\hline Ogun State & Abeokuta & 7.050 & 3.317 & 3 & 11 & 14 & 14 & 68 & 82 & 17 & 96 & 21.43 & 17.07 & 17.71 \\
\hline Ogun State & ljebu-Ode & 6.783 & 3.967 & 2 & 7 & 9 & 11 & 78 & 89 & 13 & 98 & 22.22 & 12.36 & 13.27 \\
\hline Ogun State & Iwo & 6.650 & 4.150 & 2 & 10 & 12 & 18 & 69 & 87 & 20 & 99 & 16.67 & 20.69 & 20.20 \\
\hline Ogun State & Owode & 6.948 & 3.505 & 2 & 14 & 16 & 15 & 55 & 70 & 17 & 86 & 12.50 & 21.43 & 19.77 \\
\hline Ondo State & Akure & 7.253 & 5.192 & 1 & 14 & 15 & 14 & 58 & 72 & 15 & 87 & 6.67 & 19.44 & 17.24 \\
\hline Ondo State & Fajaw & 6.450 & 4.967 & 0 & 17 & 17 & 15 & 56 & 71 & 15 & 88 & 0.00 & 21.13 & 17.05 \\
\hline Ondo State & Idanre & 7.151 & 5.109 & 0 & 14 & 14 & 19 & 66 & 85 & 19 & 99 & 0.00 & 22.35 & 19.19 \\
\hline Ondo State & Ikare & 7.533 & 5.667 & 1 & 15 & 16 & 21 & 68 & 89 & 22 & 105 & 6.25 & 23.60 & 20.95 \\
\hline Plateau State & Jos & 9.882 & 8.969 & 7 & 37 & 44 & 9 & 42 & 51 & 16 & 95 & 15.91 & 17.65 & 16.84 \\
\hline Plateau State & Pankshin & 9.327 & 9.443 & 6 & 33 & 39 & 16 & 36 & 52 & 22 & 91 & 15.38 & 30.77 & 24.18 \\
\hline Plateau State & Rukuba & 9.882 & 8.885 & 5 & 34 & 39 & 11 & 42 & 53 & 16 & 92 & 12.82 & 20.75 & 17.39 \\
\hline Plateau State & Shendam & 8.877 & 9.527 & 8 & 33 & 41 & 17 & 43 & 60 & 25 & 101 & 19.51 & 28.33 & 24.75 \\
\hline Sokoto State & Bafarawa & 13.317 & 6.650 & 10 & 34 & 44 & 14 & 42 & 56 & 24 & 100 & 22.73 & 25.00 & 24.00 \\
\hline Sokoto State & Bodinga & 12.875 & 5.167 & 4 & 33 & 37 & 14 & 39 & 53 & 18 & 90 & 10.81 & 26.42 & 20.00 \\
\hline Sokoto State & Goronyo & 13.433 & 5.667 & 12 & 37 & 49 & 10 & 38 & 48 & 22 & 97 & 24.49 & 20.83 & 22.68 \\
\hline Sokoto State & Sokoto & 13.033 & 5.267 & 9 & 33 & 42 & 11 & 39 & 50 & 20 & 92 & 21.43 & 22.00 & 21.74 \\
\hline Taraba State & Garbabi & 7.838 & 11.035 & 9 & 22 & 31 & 14 & 41 & 55 & 23 & 86 & 29.03 & 25.45 & 26.74 \\
\hline Taraba State & Kassa & 8.822 & 11.643 & 14 & 28 & 42 & 23 & 46 & 69 & 37 & 111 & 33.33 & 33.33 & 33.33 \\
\hline Taraba State & Maihula & 7.989 & 10.995 & 10 & 26 & 36 & 17 & 33 & 50 & 27 & 86 & 27.78 & 34.00 & 31.40 \\
\hline Taraba State & Wukari & 7.866 & 9.765 & 7 & 27 & 34 & 14 & 48 & 62 & 21 & 96 & 20.59 & 22.58 & 21.88 \\
\hline Total & - & - & - & 101 & 377 & 478 & 170 & 489 & 659 & 271 & 93.5 & 21.15 & 25.59 & 23.74 \\
\hline
\end{tabular}


TABLE 2-A1: Nigerian individual state peste des petits ruminants virus seroprevalence data based on species of small ruminants, $2010-2013$.

\begin{tabular}{|c|c|c|c|c|c|c|c|c|c|c|c|c|}
\hline Province & SheepPos & SheepNeg & SheepTotal & Prev_sheep & GoatsPos & GoatsNeg & GoatTotal & Prev_goats & TotalPos & TotalNeg & Total & Prevalence \\
\hline Anambra & 0 & 13 & 13 & 0.00 & 74 & 292 & 366 & 20.22 & 74 & 305 & 379 & 19.53 \\
\hline Akwa Ibom & 1 & 7 & 8 & 12.50 & 94 & 277 & 371 & 25.34 & 95 & 284 & 379 & 24.80 \\
\hline Adamawa & 24 & 122 & 146 & 16.44 & 52 & 181 & 233 & 22.32 & 76 & 303 & 379 & 20.05 \\
\hline Imo & 2 & 4 & 6 & 33.33 & 100 & 273 & 373 & 26.81 & 102 & 277 & 379 & 26.91 \\
\hline Taraba & 40 & 103 & 143 & 27.97 & 66 & 170 & 236 & 27.97 & 106 & 273 & 379 & 28.50 \\
\hline Plateau & 26 & 137 & 163 & 15.95 & 53 & 163 & 216 & 24.54 & 79 & 300 & 379 & 20.84 \\
\hline Kano & 52 & 105 & 157 & 33.12 & 54 & 168 & 222 & 24.32 & 106 & 273 & 379 & 27.97 \\
\hline Ogun & 9 & 42 & 51 & 17.65 & 58 & 270 & 328 & 17.68 & 67 & 312 & 379 & 17.68 \\
\hline Kwara & 43 & 95 & 138 & 31.16 & 58 & 183 & 241 & 24.07 & 101 & 278 & 379 & 26.65 \\
\hline Ondo & 2 & 60 & 62 & 3.23 & 69 & 248 & 317 & 21.77 & 71 & 308 & 379 & 18.73 \\
\hline Cross River & 0 & 0 & 0 & - & 56 & 323 & 379 & 14.78 & 56 & 323 & 379 & 14.78 \\
\hline Sokoto & 35 & 137 & 172 & 20.35 & 49 & 158 & 207 & 23.67 & 84 & 295 & 379 & 22.16 \\
\hline
\end{tabular}

TABLE 3-A1: Peste des petits ruminants virus seroprevalence data based on category of small ruminants in Nigeria, $2010-2013$.

\begin{tabular}{|c|c|c|c|c|c|c|c|c|c|c|c|c|c|c|c|c|c|c|c|c|c|c|c|c|}
\hline rovi & $\begin{array}{l}\text { IA } \\
\text { os }\end{array}$ & & $\begin{array}{l}\text { A } \\
\text { os }\end{array}$ & & $\begin{array}{l}\text { GMA } \\
\text { pos }\end{array}$ & $\begin{array}{l}\text { GMY } \\
\text { pos }\end{array}$ & & $\begin{array}{l}\text { Y } \\
\text { s }\end{array}$ & $\begin{array}{c}\text { SMA } \\
\text { neg }\end{array}$ & & & $\begin{array}{l}\text { SFY } \\
\text { neg }\end{array}$ & $\begin{array}{c}\text { GMA } \\
\text { neg }\end{array}$ & $\begin{array}{l}\text { GMY } \\
\text { neg }\end{array}$ & $\mathrm{G}$ & & & & & & & & $\begin{array}{c}\text { Prev } \\
\text { SFY }\end{array}$ & $v_{-}$ \\
\hline & 0 & 0 & 0 & 0 & 1 & 1 & 2 & 21 & 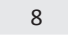 & 0 & 5 & 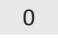 & 6 & 66 & 85 & 73 & 0.00 & 7 & 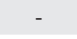 & 8 & 0.00 & 02 & 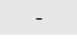 & 2.34 \\
\hline om & 1 & 0 & 0 & 0 & 11 & 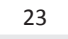 & - & 24 & - & - & 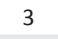 & - & & 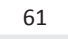 & 0 & - & & 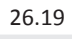 & 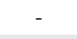 & 7.38 & 0.00 & 8 & 0 & 97 \\
\hline & 1 & 0 & 1 & 0 & 29 & 18 & 32 & 21 & 1 & 0 & 3 & 0 & & 56 & & 67 & & & - & & & & 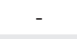 & 36 \\
\hline & 13 & 6 & 16 & 3 & 21 & 7 & 26 & 14 & S & 11 & 4 & 1 & 50 & 17 & 12 & 29 & & 29.30 & 53.25 & 29.17 & 28.57 & 3 & 1 & 56 \\
\hline Tated & 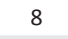 & 2 & 12 & 4 & 10 & 1 & 21 & 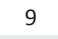 & 45 & 12 & 57 & 23 & 48 & 17 & 00 & 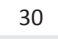 & (5 & 0 & 29 & 17 & 39 & 60 & 81 & 3.08 \\
\hline Dgun & 5 & 0 & 3 & 1 & 11 & 8 & 27 & 12 & 14 & 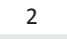 & 21 & 5 & 5 & 25 & 69 & 26 & 26.32 & 18.03 & .00 & 24.24 & 2.50 & 8.13 & 16.67 & 31.58 \\
\hline iwara & 11 & 4 & 16 & 12 & 21 & 9 & 23 & 5 & 32 & 12 & 45 & 6 & 68 & 2 & 68 & 2 & 25.58 & 23.60 & 25.00 & .47 & 6.23 & 5.27 & 66.67 & 18.52 \\
\hline ad & 1 & 0 & 1 & 0 & 13 & 8 & 32 & 16 & 17 & 11 & 20 & 12 & 7 & 49 & 81 & 4 & 5.56 & 8 & 00 & 4 & 4.76 & 2 & .00 & 5.40 \\
\hline $\mathrm{Crncs} R$ & 0 & 0 & 0 & 0 & 1 & 1 & 2 & 4 & 0 & 0 & 0 & 0 & 76 & 73 & 120 & 54 & - & 12.64 & 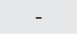 & 19.78 & - & 8 & 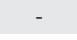 & 90 \\
\hline & - & 4 & 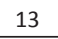 & . & -1 & 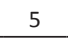 & 2 & 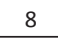 & - & ts & ( & 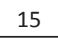 & . & 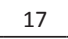 & 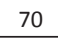 & -1 & 20.75 & (5) & 25.00 & 2.75 & 8.31 & & 28.57 & 23.53 \\
\hline Jan & 74 & 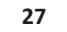 & 95 & Jo & 93 & 29 & 303 & 160 & 288 & 86 & 344 & 107 & 673 & 455 & 971 & 506 & 20.44 & 23.89 & 21.64 & 26.21 & 22.29 & 22.09 & 23.78 & 24.02 \\
\hline
\end{tabular}

